\title{
A Purposive approach to Whistleblower Protection: \\ A COMMENT ON MERK V. INTERNATIONAL ASSOCIATION \\ OF BRIDGE, STRUCTURAL, ORNAMENTAL AND \\ REINFORCING IRON WORKERS, LOCAL 771
}

\author{
SFAN C. DOYLE:
}

\section{INTRODUCTION}

Whistleblowing may be defined as the "disclosure by organization members ... of illegal, immoral or illegitimate practices under the control of their employers, to persons or organizations that may be able to effect action."' In Canada, statutory protection designed explicitly ${ }^{2}$ for whistleblowers has been enacted in three provinces, ${ }^{3}$ as well as by Parliament, ${ }^{4}$ which has made retaliation against whistleblowers a criminal offence. Merk v. International Association of Bridge. Sirwctural. Ornamemal and Reinforcing Iron Workers, Local 771.5 which arose under the Saskatchewan legislation. is the first decision in which the Supreme Court of Canada has considered the nature and scope of statutory whistleblower protection. At issue was whether coverage should be limited to employees that disclose wrongdoing externally to state actors, or extended to those who work internally to rectify wrongdoing.

\section{FAcTS}

Merk was employed as the office manager and bookkeeper of a local of the Iron Workers union. She noticed irregularities in the expense claims of her two immediate superiors, who appeared to be seeking reimbursement of expenses either not incurred. or to which they were not entitled. Merk ultimalely raised her concerns with in investigator appointed by the international union and, unsatislied with the response, wrote to the international president warning that unless that body intervened, the matter would be referred to the police. After the international union had received this letter, the local lired Merk. Merk then brought a private prosecution against the local, alleging that her dismissal violated s. 74(1)(a) of the Saskatchewan Labour Standurds Act. ${ }^{6}$ The central issue was whether the officials of the international union constituted a "lawful authority" within the meaning of the $L S A$.

B.A.. M.I.R., LL.B., IL.M. of the Ontario bar. I am indebted to Brian Elherington of the University of Windsor, for his helptul comments on an earlier paper, portions of which form the basis of this comment.

1 Terry Morehead Dworkin, "Whistleblewing, MNCs, and Pe:ace" (2002) 35 Viand. J. Transinat'I L. 457 at $\mathbf{4 6 1}$ [references omitted].

: As opposed to ancillary protection contained in statutes having purposes other than the disclosure of wrongdoing (such as human rights and lahour standards legislation). which prolect employecs only to the extent necessary to realize the underlying statutory objectives. Such chactments do not "give employes the message that they are 10 be generalized walchdogs against organizational wrongdoing." See Marcia P. Miceli \& Janci P. Near, Bhowing the Whistle: The Orgemizationst and l .egal Implications for Companies and Employeses (New York: Lexington Books. 1992) at 2.34.

- The provinces are New Brinswick. hy virtue of s. 28 (c) of the timplenmem Stumderds Act. S.N. R. 1982. c. 1:-7.2: Saskatchewan under s. 74(1) of the I.choour Situmderds Act. R.S.S. 1978. c. I.-1, as an. by S.S. 1994, c. 39 [I.S.I]; and Nova Scotia, which protects public servants under the Civil Service Disciesure of Wrongdoing Regututions. N.S. Reg. 205/2004.

Criminal code, R.S.C. 1985, c. C-46, as am. by S.C. 2004, c. 3, s. 425.1 .

2005 SCC 70. [2005] 3 S.C.R. 425 [Merk].

Stupra note 3. 


\section{Statutory Provision in IsSUE}

The relevant provisions of s. 74 of the $L S A$ are as follows:

(1) No employer shall discharge or thruaten to discharge or in any manner discriminate against an employee because the employec:

(a) has reported or proposed to report to a lawful authority any activity that is or is likely to result in an offence pursuant to an Act or an Act of the Parliament of Canada; ...

(2) Subsection (1) does not apply where the actions of an employee are vexatious.

\section{The Courts Below}

\section{A. Provincial Court Decision}

The Court held that Merk was terminated because she had complained to union officials about the payment of expenses to a superior, and that it was reasonable for her to have believed that some of the expenditures constituted a fraud upon the union. The Court also found, however, that the local had decided to terminate Merk before it had leamed of her threat to go to the police. The case therefore turned on whether the international union to which Merk had complained constituted a "lawful authority" within the meaning of the $L S A$. Although McMurtry J. recognized that the international president had the authority to remove an officer from his or her position, she concluded that "lawful authority" meant "a person or institution authorized by law to investigate offences." On this interpretation, Merk could not prove an essential element of the offence, and the charge against the local was dismissed.

\section{B. QueEn's BenCh DECISION}

Justice Ball upheld the narrow interpretation of "law ful authority," although he recognized the statutory basis of the union's right to administer its internal affairs, and that the international president had the authority to discipline Merk's superiors for receiving payments in contravention of the union constitution. In his view, "lawful authority" meant "a body with authority conferred by an Act to enforce the provisions of that Act." Since the international union could not lawfully prosecute an offence under a federal or provincial enactment, the Court held that it did not fall within the scope of s. 74 .

Merk v. Infermational Association of Bridge. Structural. Ormamental and Reinforcing Iron Workers. Local 771, 2002 SKPC 78, [2002] S.J. No. 555 at para. 19 (QL).

R. v. Imernational Association of Bridge. Structural. Omamental and Reinforcing Iron Workers, Local 771, 2003 SKQB 9, 229 Sask. R. 37 al paras. 40-41. 


\section{Court of APpeal Decision}

A majority of the Court of Appeal held that the use of the term "lawful authority" in close proximity to the phrase "offence pursuant to an Act or an Act of the Parliament of Canada" meant that the "lawful authority must be one that is capable of exercising authority, i.e., compelling obedience, with respect to the conduct reported as an offence." ${ }^{(4)}$ The Court further held that the historical and purposive context supports a narrow interpretation, since the definition of "lawful authority" remained unchanged even as the scope of the LSA was expanded, and because it found that the provision was not enacted to "codify all relationships between employer and employee," of illegality to state actors "cloaked with authority to compel obedience." "Finally, the Court held that as a "penal statute," the $L S A$ must be construed nartowly, with any ambiguities being resolved in favour of an accused."

\section{Supreme Court of Cavada Decision}

By a majority of six to one, the Court held that "lawful authority" includes not only public bodies capable of treating an allegation qua offence, but officials within an organization who "exercise lawful authority over the employee(s) complained about, or over the activity that is or is likely to result in the offence." As the international union had the lawful authority to respond to allegations of financial impropriety by its officers, the local violated the $L S A$ by firing Merk for having complained to the international about the conduct of her superiors. A conviction was therefore entered, and the matter remitted back to the trial judge to consider sentencing, as well as Merk's claim for relief.

Writing for the majority, Binnie J. began his analysis by observing that the goal behind statutory whistleblower protection is to "recruit employees to assist the state in the suppression of unlawful conduct ... by providing employees with a measure of immunity against employer retaliation."14 The issue, therefore, was whether the legislative intention is best achieved by limiting protection to employees that disclose wrongdoing externally to state actors, or by also protecting those that report misconduct internally "in an effort to have the 'activity' terminated rather than prosecuted."15

Justice Binnic next held that the determining factor in the interpretation of "lawful authority" is not "whether the authority is public or private, but whether it is lawful," and he recognized that within the employment law context an "employee"s duty of loyalty and the public's interest in whistleblowing is best reconciled with the "up the ladder' approach."1? Although finding that the plain meaning of "lawful authority" includes private as well as

R. v. International Associotion of Bridge. Sirucural. Ormumemal and Reinfurcing Iron Workers. Local 771, 2003 SKCA 103. 238 Sask. R. 234 at para. 20.

Ibid. at para. 23.

lbid, at para. 22.

Ibid. at para. 25.

Supra note 5 at para. 38.

lbid. at para. 14.

Jbid. at para. 15.

lbid.

Ibid. at para. 16. 
public bodies, Binnie J. went on to identify seven factors from the contextual approach to statutory construction that, in his view, further support a liberal interpretation of s. 74 .

\section{A. Grammatical and Ordinary SENSE}

The Court held that the reference to "offence" in $s .74$ refers to the type of activity the legislature wished to counter by having it brought to the attention of those with the lawful authority to appropriately respond. "While the response ... could include prosecution," Binnie J. reasoned, "it could also include steps short of prosecution through action by an employer ... to put a stop to the wrongful conduct."18 In this case, the international president was not a state actor, but had the lawlul authority by virtue of his office to stop the financial improprieties at the local. Moreover, there was "nothing in the "grammatical and ordinary meaning" of $\mathrm{s}$. 74 to cast doubt on this broader interpretation of "lawful authority."

\section{B. THE SCHEME OF THE LABOUR STANDARDS ACT}

As "essentially employec protection legislation." Binnie J. held that the $L S A$ must be construed generously, with any ambiguities being resolved in favour of Merk."

\section{THE OBJECT OF THE LABOUR STANDARDS ACT}

The Court found that $\mathrm{s}$. 74 represents a balance between an employee's duty of loyalty to the employer and the public interest in countering illegality, which the labour arbitration jurisprudence reveals is "best achieved if "loyal" employees are encouraged to resolve the problems internally rather than marching forthwith to the police." narrow interpretation would deny protection to the loyal employec that seeks to resolve matters internally, and protect only those that report wrongdoing externally to a state actor. The Court characterized this as "the antithesis of good labour relations policy."22

\section{The Public Policy Debate}

As the failure to exhaust internal means of redress has been "condemned by courts, labour arbitrators and other commentators as prima facie disloyal and inappropriate conduct," Court held that it would be anomalous to require employees to disclose wrongdoing externally to qualily for protection. It would also be inconsistent with the practice in Great

is $\quad$ bid. at para. 19.

14 Hid.

:o Thid. at paras. 20, 22.

$\therefore \quad \mathrm{Wid}$. at para. 23. In support of the obligation to exhaust intemal channels, the Court referenced Re Minismy of Afrome General. Condctions Branch and British Columbio Govermmen Employees Union (1981), 3 L.A.C. (3d) 140 (B.C. Arb. Bd.) at 163 [Rc . Ministry of Anorney General]; Haydon v. Camada,

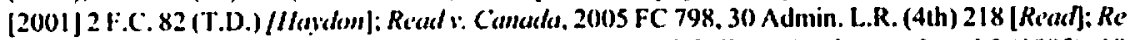
Simon Fraser University and Association of Universing and College Employees, Local 2 (1985), 18 1.A.C. (3d) 361 (B.C. Arb. Bd.); Re Forgie amd Trecasury Board, [1986] C.P.S.S.R.B. No. 310; Re Treaswy Bowrl (Employment d Immigration) and Quigley (1987), 31 L.A.C.(3d) 156 (C.P.S.S.R.13.); and Healh Core Corp. of St. Jolm's, j2001] Nfld. L.A.A.A. No. I.

$\because \quad$ Merk, ibid.

$\because \quad$ lbid. at para. 25. 
Britain, New Zealand, and the European Union, where the Court noted that employees must, with few exceptions, first raise allegations of wrongdoing internally within the organization. The legislature could not, therefore, have intended to "expose "loyal' employees to employer retaliation without a remedy."24

\section{E. AVOIDANCE OF ANOMALous Results}

The Court observed that a narrow interpretation of "lawful authority" would enable an employee to be dismissed with impunity for having reported wrongdoing internally, and to be protected under the $L S A$ only if he or she complains to the state. Such a result, Binnic J. reasoned, "invites rejection on the basis of irrationality." "s

\section{F. Legislative History}

In the Court's view, s. 74 is not simply an "incremental advance on an earlier immunity clause" 20 designed to protect employees that invoke the protection of the LSA by filing complaints, furnishing information to the state, or testifying in an investigation or proceeding under the statute. Rather, it is properly characterized as a "broader legislative reform" that is not prima facie "directed to cooperation between employees and government oflicials."27 The Court then contrasted s. 74 of the LSA with s. 425.1 of the Criminal Code, which criminalizes retaliation against an employee who reports illegality to "a person whose duties include the enforcement of federal or provincial law,"28 and held that the Court of Appeal had infused s. 74 with "the more restrictive language of the Criminal Code without textual or contextual justification." 29

\section{G. Penal, Provision}

Justice Binnie found the rule of strict construction to be of "limited value" when considering a regulatory statute such as the $L S A$, because "even with penal statutes, the real intention of the legislature must be sought, and the meaning compatible with its goals applied." 30 He also observed that federal and provincial interpretation statutes, which deem all legislation remedial and therefore subject to a liberal and purposive interpretation, require that any ambiguities in penal statutes be resolved in a manner consistent with the attainment of the legislative objectives "regardless of the impact on accused persons," case, penal provisions should not be construed narrowly where, as here, "other interpretive factors" favour a broader approach.".

lbid. at para. 26.

Ibid. at para. 27.

Ibid, at para. 28.

Ibid. at para. 31.

lbid. at para. 29.

lbid.

Ibid. at para. 33, rolying on $R$. 1. Ilasselwander, [1993] 2 S.C.R. 398 al 413, where Cong J. adopts a statcment of Martin J.A. in R. v: (Goulis (198I), 33 O.R. (2d) 55 (C.A.).

"Merk, ibid, quoting Ruth Sullivan, Swllivan and Driedges on the Construction of Statutes, 4th ed. (Marklıam, Ont.: Butterwortlss, 2002) at 387.

" Merk. ihid. at para. 34. 


\section{V1. Discussion}

Central to the outcome in Merk is the recognition that the objective of whistleblowing statutes is to suppress illegality, and that "steps short of prosecution," such as action by an employer halting wrongdoing, may be a legitimate response to an allegation of misconduct. These lindings are significant, because not every jurisdiction protects internal whislleblowers, and the rationale for protection depends upon whether the primary objective of whistleblower legislation is to counter unlawful activity, or assist the state in the prosecution of crime.

Where prosecution is the goal, protecting internal whistleblowers may be counterproductive, ${ }^{33}$ since internal disclosures are unlikely to spur state action against a wrongdoer. Conversely, if the objective is to stop wrongdoing, excluding internal whistleblowers from protection is unwarranted, since most employees initially disclose misconduct internally, ${ }^{34}$ and therefore protecting internal whistleblowers may facilitate a "likely and speedy solution to the wrongdoing. ${ }^{35}$

Having concluded that the objective of s. 74 of the $L S A$ is not limited to the prosecution of illegality, the Supreme Court's interpretation of "lawful authority" is consistent both with the statutory objective, as well as the liberal approach to the construction of rights-conferring legislation. A more restrictive interpretation would have undermined the legislative intention by unjustifiably withholding protection from those working internally to eradicate illegality from the workplace.

Merk is also significant because the Court recognized, for the first time, a "whistleblower exception" to the duty of loyalty owed by employees to their employers. ${ }^{36}$ On this point, Binnie J. adopted the following passage from the seminal case of Re Ministry of Altorney General:

The duty of fidelity does not mean that the Daniel Ellsbergs and Karen Silkwoods of the world must remain silent when they discover wrongdoing oceurring at their place of cmployment. Neither the public nor the employer's long-term best interests are served ir these employeses, from fear of losing their jubs, are so intimidated that they do not bring information about wrongdoing at their place of employment to the

3) In the Uniled States, for instance, a public policy emphasizing the exposure of u rongdoing may account lor the less favourable legal tramework for intemal whistleblowers, which are protecled in only a minority of states: Elletta Sangrcy Callahan, Terry Morehead Dworkin \& David Lewis, "Whistleblowing: Australian. U.K., and U.S. Approaches to Disclosure in the Public Interest" (2004) $44 \mathrm{Va}$. J. Int'l L. 779 at 890-91. For a comprehensive overview of statutory whistleblower protection in the United Stales, sec Elluta Sangrey Callahan \& Terry Morehead Dworkin. “The State of State Whistleblower Protection" (2000) 38 Am. Bus. L.J. 99.

34 Terry Moreluead Dworkin \& Elletta Sangrey Callalıan, "Internal Whistleblowing: Protecting the lnterests of the Employec, the Organization, and Sociely" ( 1991 ) 29 Am. Bus. L.J. 267 at $285,301$.

is $\quad$ thid. at 285.

in This exception was first explicitly recognized by a court in /landon, supra note 21 . Il may be argued. however, that such an exception was implicitly recognized in Fraser w. Canada, [1985] 2 S.C.R. 455 at 470 , where the Court held that the duty of loyalty did not prohibit employees from publicly criticizing the government where, inter alia, it was engaged in illegal acts, or its policies jeopardized the life, health, or salety of employees or others: see, Read, supra note 21 at paras. 60-64. 


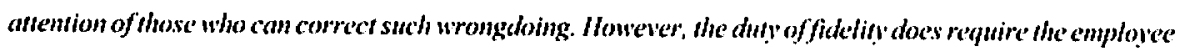
to exhoust internal "whistle-blowing" mechanisms before "going public. ${ }^{37}$

While the Court had previously recognized the existence of the duty of loyalty, it had not determined whether it obliged employees to first endeavour to resolve matters internally. The significance of Merk will therefore extend beyond claims to statutory whistleblower protection to the broader labour and employment law context, where employees may confront illegality in the workplace, but will be hard-pressed ${ }^{38}$ to justify bypassing internal channels in favour of external disclosure.

Extending protection to internal whistleblowers is also justifiable on public policy grounds. Internal disclosure "saves public funds ... accords with the actions of most whistleblowers, is less harmful to the organization and the employee, and is considered more ethical" than external disclosure. ${ }^{39}$ Moreover, most whistleblowers are "Iong-time employees, fairly high in the organization, who have a strong sense of organizational loyalty ... [who] view their whistleblowing as an effort to help the organization ... [and] would prefer to report internally." These are precisely the type of employees the law should protect and, considering the "low public visibility and high technical complexity of much illegal activity in the workplace," upon whom the state may increasingly have to rely in order to combat organizational wrongdoing.

Employers also gain from internal whistleblowing, as internal channels may protect against "unwarranted attacks based on inaccurate investigation," opportunity privately to take corrective action and thereby reduce the likelihood of lost business, adverse publicity, litigation, fines or other criminal sanctions, and other adverse consequences." 13 Further, by accessing internal mechanisms, employees may receive "additional information [that may] forestall an inaccurate disclosure, or may result in the problem's correction and prevent a needless disclosure."

Finally, by recognizing that the primary objective of whistleblower statutes is the surppression of illegality rather than the prosecution of crime, Merk is consistent with the development of whistleblower law outside of Canada, where the emphasis has shifted away from external disclosure in favour of internal reporting. representing "a change in emphasis away from a primary focus on punishment by governmental bodies toward earlicr and more complete cessation of wrongdoing." ${ }^{\text {"s }}$

Supra note 5 at para. 23 [emphasis added], relerencing Re Ministry of Attorney General, supra note 21 at 163 . Justice Binnie recognized, however, that an employee could be justified in reporting externally without utilizing internal channels, such as where he or she fears that the employer will destroy cvidence (Merk, ibid. at para. 37).

" Terance D. Miethe \& Joyce Rothschild. "Whistleblowing and the Control of Organizational Misconduct" (1994) 64 Sociological Inquiry 322 at 323. Re Ministry of Arrormey Gemeral, supra note 21 at 163 , cited Merk, supra note 5 at para. 23. Supra nole 34 at 300 [references omilted]. Martin H. Malin, "Protecting the Whistleblower from Retalialtory Discharge" (1983) 16 U. Mich. J.L. Reform 277 at 313.

45 Supra note I at 463. 


\section{Conclusion}

Merk adopts a purposive approach to the interpretation of whistleblower statutes that recognizes that the ultimate aim of such legislation is the suppression of unlawful conduct rather than the prosecution of crime. Protecting internal whistleblowers is supportive of this objective, consistent with the expansive approach to the construction of rights-conferring legislation, and in line with the development of whistleblower law outside of Canada. It is also good public policy, as it protects loyal employees, benefits employers, and serves societal interests. 